\title{
Kinetic Differences between Synaptic and Extrasynaptic GABA Receptors in CA1 Pyramidal Cells
}

\author{
Matthew I. Banks and Robert A. Pearce \\ Department of Anesthesiology, University of Wisconsin, Madison, Wisconsin 53706
}

$\mathrm{GABA}_{A}$-mediated IPSCs typically decay more rapidly than receptors in excised patches in response to brief pulses of applied GABA. We have investigated the source of this discrepancy in CA1 pyramidal neurons. IPSCs in these cells decayed rapidly, with a weighted time constant $\tau_{\text {Decay }}$ of $\sim 18 \mathrm{msec}$ $\left(24^{\circ} \mathrm{C}\right)$, whereas excised and nucleated patch responses to brief pulses of GABA ( $2 \mathrm{msec}, 1 \mathrm{~mm}$ ) decayed more than three times as slowly $\left(\tau_{\text {Decay }}, \sim 63 \mathrm{msec}\right)$. This discrepancy was not caused by differences between synaptic and exogenous transmitter transients because (1) there was no dependence of $\tau_{\text {Decay }}$ on pulse duration for pulses of $0.6-4 \mathrm{msec}$, (2) responses to GABA at concentrations as low as $10 \mu \mathrm{M}$ were still slower to decay ( $\tau_{\text {Decay }}, \sim 41 \mathrm{msec}$ ) than IPSCs, and (3) responses of excised patches to synaptically released GABA had decay times similar to brief pulse responses. These data indicate that the receptors mediating synaptic versus brief pulse responses have different intrinsic properties. However, synaptic receptors were not altered by the patch excision process, because fast, spontaneous IPSCs could still be recorded in nucleated patches. Elevated calcium selectively modulated patch responses to GABA pulses, with no effect on IPSCs recorded in nucleated patches, demonstrating the presence of two receptor populations that are differentially regulated by intracellular second messengers. We conclude that two receptor populations with distinct kinetics coexist in CA1 pyramidal cells: slow extrasynaptic receptors that dominate the responses of excised patches to exogenous GABA applications and fast synaptic receptors that generate rapid IPSCs.

Key words: $G A B A_{A}$ receptors; hippocampus; receptor kinetics; IPSCs; patch clamp; extrasynaptic receptors
The time course of synaptic transmission at synapses that use "fast" ligand-gated ion channels is determined primarily by the kinetics of the receptor/ionophore in response to a brief, high concentration of neurotransmitter (Clements et al., 1992; Maconochie et al., 1994; Jones and Westbrook, 1995; Legendre, 1998; but see, Frerking and Wilson, 1996). For glutamate receptors, the currents generated by AMPA and NMDA receptors in response to rapidly applied pulses of ligand have onset and decay kinetics similar to synaptic currents mediated by these receptors (Trussell and Fischbach, 1989; Lester et al., 1990; Clements et al., 1992; Colquhoun et al., 1992; Dudel et al., 1992; Hestrin, 1992). For $\mathrm{GABA}_{\mathrm{A}}$ receptors, however, responses of receptors in excised patches to brief ( $\sim 2 \mathrm{msec})$, exogenous GABA applications typically decay more slowly than $\mathrm{GABA}_{\mathrm{A}}$ receptor-mediated synaptic currents (Galarreta and Hestrin, 1997; Jones and Westbrook, 1997; Mellor and Randall, 1997; Mozrzymas et al., 1999; Perrais and Ropert, 1999). Although patch currents, or "simulated IPSCs", are often described as being similar to synaptic GABA currents, the decay time constants of patch responses exceeded those of synaptic responses in these studies by 70 to $>400 \%$. This discrepancy is comparable to the effects of benzodiazepines and general anesthetics on $\mathrm{GABA}_{\mathrm{A}}$ receptor-

Received Oct. 7, 1999; revised Nov. 8, 1999; accepted Nov. 15, 1999.

This work was supported by National Institutes of Health Grant GM55719 (R.A.P.), University of Wisconsin-Howard Hughes Medical Institute Research Resources Program, and the Department of Anesthesiology, University of Wisconsin-Madison. Thanks to Donna Cole and Philippe Shils for technical support. Dr. Pearce is the Betty J. Bamforth Research Professor of Anesthesiology.

Correspondence should be addressed to Dr. Matthew I. Banks, Department of Anesthesiology, University of Wisconsin, 43 Bardeen Laboratories, 1300 University Avenue, Madison, WI 53706. E-mail: mibanks@facstaff.wisc.edu.

Copyright (C) 2000 Society for Neuroscience 0270-6474/00/200937-12\$15.00/0 mediated IPSCs (Vicini et al., 1986; Tanelian et al., 1993), and thus may have significant functional consequences.

This discrepancy in kinetics could arise because excised receptors differ in some way from synaptic receptors or because the transmitter application differs from the synaptic transient. How might excised receptors differ from synaptic receptors? Synaptic receptors are regulated by cytoskeletal elements (Rosenmund and Westbrook, 1993) and phosphorylation systems (Jones and Westbrook, 1997). It is possible that the process of patch excision disrupts such interactions to alter the intrinsic kinetics of the receptors. Alternatively, excised patches may contain primarily extrasynaptic receptors with different kinetic properties (Tia et al., 1996a), possibly because of differences in subunit composition between extrasynaptic and synaptic receptors (Nusser et al., 1998; Brickley et al., 1999). Differences attributable to agonist application include time course and concentration, the identity of the transmitter itself, the presence of synaptically released cofactors, or the presence of extracellular modulatory agents.

To investigate these issues, we have compared the responses of receptors in patches excised from the somata of CA1 pyramidal cells with spontaneous $\mathrm{GABA}_{\mathrm{A}}$ receptor-mediated IPSCs recorded in these cells. We found that under our experimental conditions, the deactivation kinetics of receptors in excised patches never matched the decay kinetics of fast IPSCs, regardless of the concentration or time course of transmitter, or the presence of cofactors such as $\mathrm{H}^{+}$or $\mathrm{Zn}^{2+}$ ions. Rather, our data suggest that excised receptors represent primarily extrasynaptic receptors and that these receptors have intrinsic kinetics that differ substantially from those of synaptic receptors.

\section{MATERIALS AND METHODS}

Slice preparation. Young rats ( 8 to 24 -d-old) were decapitated under halothane anesthesia, and the head was immediately immersed in cold 
$\left(4^{\circ} \mathrm{C}\right)$ artificial CSF (ACSF) (in mm: $\mathrm{NaCl} 127, \mathrm{KH}_{2} \mathrm{PO}_{4}$ 1.21, $\mathrm{KCl} 1.87$, $\mathrm{NaHCO}_{3} 26, \mathrm{CaCl}_{2} 2.17, \mathrm{MgSO}_{4} 1.44$, and glucose 10) saturated with $95 \% \mathrm{O}_{2}$ and $5 \% \mathrm{CO}_{2}$. A block of tissue containing both hippocampi was dissected out with the brain immersed in ACSF, and the tissue was glued to a vibratome tray with cyanoacrylate glue. Slices $(400 \mu \mathrm{M})$ were cut and then held submerged at $35^{\circ} \mathrm{C}$ for $1 \mathrm{hr}$ before transfer to the recording chamber, which was perfused at $3 \mathrm{ml} / \mathrm{min}$ with ACSF saturated with $95 \%$ $\mathrm{O}_{2}$ and $5 \% \mathrm{CO}_{2}$ at $24^{\circ} \mathrm{C}$.

Patch-clamp electrophysiology. Cells in stratum pyramidale of CA1 were visualized using a video camera (Hamamatsu C2400; Hamamatsu, Tokyo, Japan) connected to an upright microscope (Axioskop; Carl Zeiss, Thornwood, NY) equipped with an infrared bandpass filter (model D775/220; Chroma Technology, Brattleboro, VT), a long workingdistance water-immersion objective (Achroplan 40×; 0.75 numerical aperture; Carl Zeiss) and differential interference contrast optics. Whole-cell recordings were obtained at room temperature $\left(24^{\circ} \mathrm{C}\right)$, using an Axopatch 1D (Axon Instruments, Foster City, CA) patch-clamp amplifier. All data were recorded using pClamp software (Axon Instruments). Data were filtered at $5 \mathrm{kHz}$, then sampled at $10-20 \mathrm{kHz}$ (Digidata 1200; Axon Instruments) and stored on a Pentium-based personal computer (PC). Patch pipettes were fabricated from borosilicate glass (1.7 mm outer diameter, $1.1 \mathrm{~mm}$ inner diameter; KG-33; Garner Glass, Claremont, CA) using a two-stage puller (Flaming-Brown model P-87; Sutter Instruments, Novato, CA), fire-polished and coated with Sylgard (Dow-Corning Company, Midland, MI) to reduce electrode capacitance. Tight-seal whole-cell recordings were obtained using standard techniques (Hamill et al., 1981; Edwards et al., 1989). Patch pipettes had open-tip resistances of 2-4 M $\Omega$ when filled with the recording solution (in $\mathrm{mM}$ : CsCl 140, Na-HEPES 10, BAPTA 10, MgATP 2, and QX-314 5, pH 7.3). Access resistances were typically 10-20 M $\Omega$ and were then compensated at $60-80 \%$. All data were recorded at a holding potential of $-60 \mathrm{mV}$. $\mathrm{GABA}_{\mathrm{A}}$ IPSCs were isolated by bath application of $20 \mu \mathrm{M}$ CNQX and 40 $\mu \mathrm{M}$ D,L-APV to block AMPA- and NMDA-mediated currents and by the inclusion of $\mathrm{CsCl}$ and $\mathrm{QX}-314$ in the patch pipette to block $\mathrm{GABA}_{\mathrm{B}^{-}}$ mediated currents. The remaining currents were completely blocked by bath application of $10 \mu \mathrm{M}$ bicuculline (data not shown). Miniature, i.e., action potential-independent, spontaneous IPSCs were recorded in the presence of $1 \mu \mathrm{M}$ tetrodotoxin (TTX).

APV, CNQX, TTX, and bicuculline were prepared at $50-100 \times$ stock solutions in $0.9 \%$ saline and applied using syringe pumps (model 551111; Harvard Apparatus, Natick, MA) set to flow at 1-2\% of the ACSF flow rate to achieve the desired bath concentrations.

Rapid agonist application. Excised or nucleated (Sather et al., 1992) outside-out patches were obtained from the somata of CA1 pyramidal cells and exposed to ligand using a rapid application system consisting of a two-barrel "theta" application pipette (fashioned from Thin Theta; Sutter Instruments) connected to a piezoelectric stacked translator (model P-245.50; Physik Instrumente, Costa Mesa, CA). Using gravity feed, solutions flowing through the application pipette could be exchanged in approximately 10 seconds via a series of low-volume, zero unswept volume, manually controlled Teflon valves (model 1126; Omnifit Limited, Cambridge, UK). The flow rate out of the tip of the theta pipette was 4.8 $\mu \mathrm{l} / \mathrm{sec}$ out of a barrel with a diameter of $300 \mu \mathrm{m}$, giving a forward velocity of $\sim 70 \mu \mathrm{m} / \mathrm{msec}$. The voltage input to the high-voltage amplifier (model P-270; Physik Instrumente) used to drive the stacked translator was filtered $(300 \mathrm{~Hz})$ using an 8-pole Bessel filter (model 902LPF; Frequency Devices, Haverhill, MA) to reduce oscillations arising from rapid acceleration of the pipette.

Solution exchange rates $(10-90 \%$ in $500 \mu \mathrm{sec})$ were estimated by measuring open tip junction currents with dilute perfusion solution at the conclusion of each experiment. The duration of the agonist pulse was defined by measuring the time between the points at $10 \%$ of peak amplitude of the junction current. Previous studies have demonstrated that this estimate is adequate for excised patches (Trussell and Fischbach, 1989). However, because of the large amount of membrane at the tip of the pipette, the exchange time around a nucleated patch is likely to be substantially slower than indicated by the open tip exchange time. We tested the solution exchange time directly by activating voltage-gated $\mathrm{K}$ currents in the nucleated patches and altering $\left[\mathrm{K}^{+}\right]$during the voltage step. Using this technique, we found that the solution exchange proceeded monoexponentially with $\tau_{\text {Exchange }}=1.7 \pm 0.2 \mathrm{msec}(n=4$; in these patches, the open tip exchange time constant was $0.2 \pm 0.1 \mathrm{msec}$ ). This exchange rate is further corroborated by experiments using the low-affinity agonist taurine, which unbinds rapidly from the $\mathrm{GABA}_{\mathrm{A}}$ receptor (Zhu and Vicini, 1997), similar to $\beta$-alanine (Jones et al., 1998).
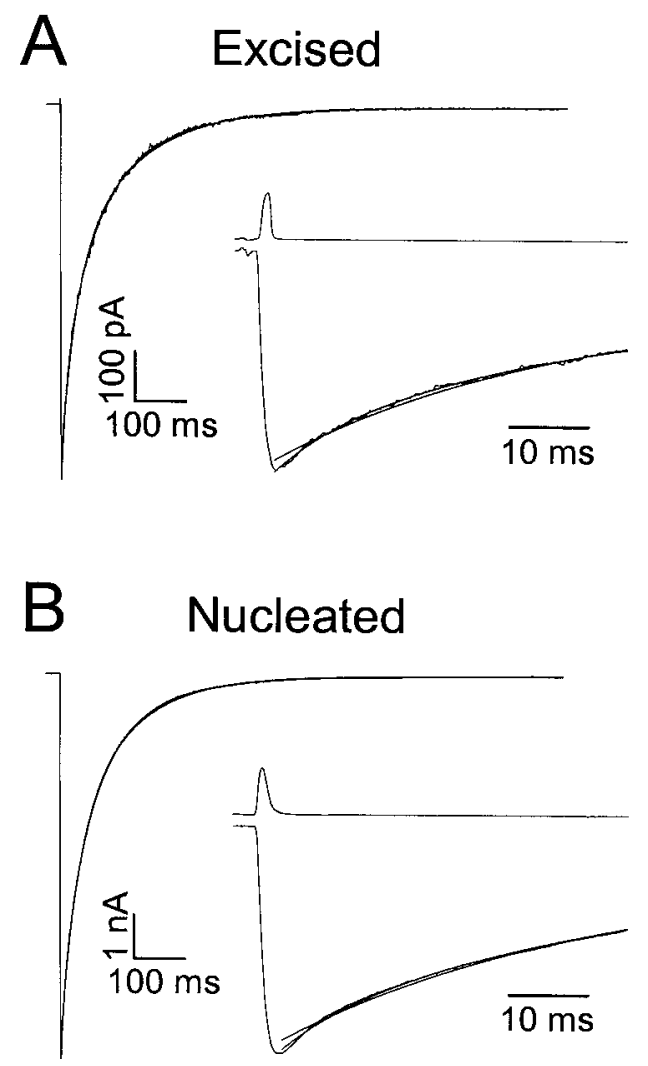

Figure 1. Kinetics of excised and nucleated patch responses. A, Averaged responses to brief exogenous pulses of GABA ( $2.0 \mathrm{msec}, 1 \mathrm{~mm})$ recorded in an excised outside-out patch taken from the soma of a CA1 pyramidal cell. Top trace shows the open-tip junction current recorded immediately after terminating the recording. Inset shows data plotted on an expanded time scale, to illustrate superior fit obtained with three versus two exponential components. Biexponential fit parameters were $\tau_{\text {Dec1,2 }}=29.4$ $(50 \%)$ and $129.8 \mathrm{msec}$. Triexponential fit parameters were $\tau_{\mathrm{Dec} 1,2,3}=10.4$ (23\%), $61.7(52 \%)$, and $173.3 \mathrm{msec}$. B, Same as $A$, but for a nucleated patch obtained from a different cell. Note difference in vertical calibration. Biexponential fit parameters were $\tau_{\mathrm{Dec} 1,2}=32.9(50 \%)$ and $112.7 \mathrm{msec}$. Triexponential fit parameters were $\tau_{\text {Dec1,2,3 }}=9.88(17 \%), 56.7(59 \%)$, and $145.2 \mathrm{msec}$.

We found that brief pulses of $20 \mathrm{~mm}$ taurine elicited currents that deactivated monoexponentially, with $\tau_{\text {Decay }}=1.8 \pm 0.1 \mathrm{msec}(n=19)$, similar to $\tau_{\text {Exchange }}$ measured using $\mathrm{K}$ currents. Finally, the similarity in decay kinetics between nucleated patches and excised patches (Fig. 1), which are likely to have much faster exchange times, suggests that the deactivation kinetics were not grossly distorted by slow exchange in nucleated patches. Access resistance and capacitance of nucleated patches were measured using the amplifier circuitry. Series resistance was compensated $80-90 \%$, yielding errors in $V_{\text {Hold }}$ caused by uncompensated series resistance of $4.4 \pm 0.6 \mathrm{mV}$.

Sniffer patch experiments. To expose excised receptors to synaptically released GABA, "sniffer patches" (Isaacson et al., 1993) were formed by excising an outside-out patch from the soma of a CA1 pyramidal cell and then reinserting the patch back in the slice. Synaptic responses in sniffer patches were elicited under identical conditions as for whole-cell synaptic responses, i.e., in the presence of CNQX and APV, and the magnitudes of the electrical stimuli applied (typically $\sim 10 \mu \mathrm{A}$ ) were the same as in whole-cell before patch excision. For each patch, the position at which responses with the most rapid rise times were measured was assumed to be the closest to synaptic release sites, and the data at this position was averaged to yield rise times, decay times, and peak amplitude for that patch.

Surface area measurements. The somatic surface area was measured in two ways. In the first method, direct anatomical measurements were made of the width and length of the somata of pyramidal cells in our slices from video photomicrographs taken of cells in slices before patch- 
Table 1. Kinetic parameters for excised and nucleated patch responses to four different GABA concentrations and for whole-cell IPSCs

\begin{tabular}{|c|c|c|c|c|c|c|c|c|c|}
\hline & $\begin{array}{c}t_{\text {Rise }} \\
(\mathrm{msec})\end{array}$ & $\begin{array}{c}\tau_{\mathrm{Dec}, 1} \\
(\mathrm{msec})\end{array}$ & $A_{1}(\%)$ & $\begin{array}{c}\tau_{\mathrm{Dec}, 2} \\
(\mathrm{msec})\end{array}$ & $A_{2}(\%)$ & $\begin{array}{c}\tau_{\mathrm{Dec}, 3} \\
(\mathrm{msec})\end{array}$ & $A_{3}(\%)$ & $\begin{array}{c}\tau_{\text {Decay }} \\
(\mathrm{msec})\end{array}$ & $n$ \\
\hline $1 \mathrm{~mm}$ GABA & $1.2 \pm 0.1$ & $13.9 \pm 1.0$ & $25 \pm 3$ & $56.8 \pm 1.9$ & $60 \pm 2$ & $199 \pm 12$ & $15 \pm 1$ & $63.9 \pm 2.6$ & 52 \\
\hline $30 \mu \mathrm{M}$ GABA & $1.6 \pm 0.1$ & $3.2 \pm 0.9$ & $37 \pm 10$ & $37.3 \pm 11.6$ & $36 \pm 10$ & $166 \pm 35$ & $29 \pm 10$ & $57.4 \pm 5.7$ & 4 \\
\hline $10 \mu \mathrm{M}$ GABA & $1.9 \pm 0.1$ & $5.0 \pm 0.5$ & $34 \pm 4$ & $31.7 \pm 4.9$ & $50 \pm 6$ & $173 \pm 33$ & $17 \pm 5$ & $41.3 \pm 2.9$ & 6 \\
\hline Whole-cell IPSC & $0.9 \pm 0.1$ & $10.9 \pm 0.5$ & $62 \pm 4$ & $31.3 \pm 1.2$ & $38 \pm 4$ & - & - & $18.4 \pm 0.5$ & 34 \\
\hline
\end{tabular}

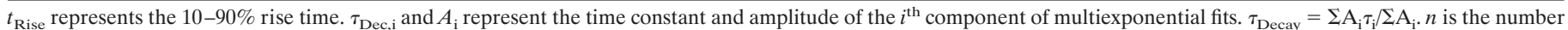
of cells or patches. Data are presented as mean \pm SEM.

ing. For the length measurements, the transition from soma to apical dendrite was defined as the point at which process diameter was one-half maximal somatic diameter. In 27 cells, the length and width were $20.0 \pm$ 0.3 and $10.0 \pm 0.5 \mu \mathrm{m}$, respectively. Somatic surface area was then estimated by assuming that the soma was a prolate spheroid, yielding an average surface area of $520 \pm 16 \mu \mathrm{m}^{2}$. In the second method, the fast component of the capacitative transient was assumed to originate from purely somatic capacitance (Jackson, 1992). In 34 cells, this component of the capacitance averaged $11.6 \pm 0.8 \mathrm{pF}$. Assuming a specific membrane capacitance of $10^{-2} \mathrm{pF} / \mu \mathrm{m}^{2}$ (Jack et al., 1983), these measurements yield a somatic surface area of $1160 \pm 80 \mu \mathrm{m}^{2}$. The discrepancy between these two values could arise because of assumptions about the exact shape of the soma, contributions of proximal dendrites to the fast capacitative transient, and small deviations in specific capacitance. We chose to use the lower estimate of $520 \mu \mathrm{m}^{2}$ in our calculations so that we would give conservative estimates of the contribution of extrasynaptic receptors to patch responses.

Nucleated patches invariably appeared spherical and typically had diameters of $5-10 \mu \mathrm{m}$, yielding surface areas of $\sim 80$ to $320 \mu \mathrm{m}^{2}$. In these patches, capacitative transients consisted of a single exponential component, with capacitance values of $1.9 \pm 0.1 \mathrm{pF}$. Assuming a specific capacitance of $10^{-2} \mathrm{pF} / \mu \mathrm{m}^{2}$, these values correspond to patch surface areas of $190 \pm 10 \mu \mathrm{m}^{2}$, consistent with direct anatomical observations. Thus, the ratio of surface area in a nucleated patch to that of the intact soma was $190 / 520=0.36$.

Data analysis. Data were analyzed on a Pentium-based PC using ClampFit (Axon Instruments), Origin (MicroCal, Northampton, MA) and StatMost (DataMost, Salt Lake City, UT). Data were filtered off-line at $2 \mathrm{kHz}$. Spontaneous events were analyzed using an automated event detection algorithm (Banks and Pearce, 1999). In this algorithm, two windows were moved along the data, a "peak" window and a "baseline" window. At each time point, the data within the two windows was averaged, and the baseline was subtracted from the peak. This yielded a "pseudodifferentiated" form of the data that was characterized by large, rapid peaks at the onset of fast $\mathrm{GABA}_{\mathrm{A}}$ IPSCs. Threshold-level crossings were determined from this pseudodifferentiated data, with threshold set as $3^{*} \sigma_{\text {Noise }}$, where $\sigma_{\text {Noise }}$ was measured during periods of no visually detectable events, and was typically $2-4 \mathrm{pA}$. Because the baseline value was constantly updated during the analysis, slow changes in baseline had no effect on the accuracy of the algorithm. Analysis was confined to $\mathrm{GABA}_{\mathrm{A} \text {,fast }}$ IPSCs, which were identified based on rise times of $<2 \mathrm{msec}$ (Banks et al., 1998). The algorithm successfully detected $>99 \%$ of spontaneous IPSCs (sIPSCs) and miniature IPSCs (mIPSCs) with these fast rise times.

To analyze the decay kinetics of fast IPSCs, a subset of events was selected for exponential curve fitting as well. Events were selected only if no other event occurred within $250 \mathrm{msec}$ of the peak. The decay kinetics of patch responses and synaptic currents was characterized by multiexponential fit parameters. For all responses to 10 and $30 \mu \mathrm{M}$ GABA, which were obtained from nucleated patches, a three exponential fit was clearly superior to two exponentials by visual inspection. For responses to $1 \mathrm{~mm}$ GABA, for 22 of 25 nucleated patches, a three exponential fit was clearly superior to two exponentials (Fig. 1), and for the remaining three patches the fast decay component was absent. In 18 of 27 excised patch responses to $1 \mathrm{~mm}$ GABA, the decays were best fit by three decay components. In four of the remaining nine patches, the fast decay component was absent, whereas in the other five patches the slow component was absent. To facilitate comparisons between data with disparate numbers of decay components, we used the weighted time constant $\tau_{\text {Decay }}=\Sigma A_{\mathrm{i}} \tau_{\mathrm{i}} / \Sigma A_{\mathrm{i}}$, where $A_{\mathrm{i}}$ is the amplitude of the $i^{\text {th }}$ component. Statistical comparisons of decay times and peak amplitudes were made using paired or unpaired Student's $t$ tests, as indicated. All data are presented as mean \pm SE.

\section{RESULTS}

\section{Kinetic differences between patch responses and IPSCs}

The synaptic transmitter transient at GABAergic synapses is believed to consist of a brief, high-concentration component, possibly followed by an extended, low-concentration tail (Jones and Westbrook, 1995, 1996; Hill et al., 1998). As an approximation to this transient, we tested the responses of $\mathrm{GABA}_{\mathrm{A}}$ receptors in excised and nucleated outside-out patches to brief (0.5-4 msec) square pulses of 1 or $10 \mathrm{~mm}$ GABA. In both excised and nucleated patches, currents in response to applications of $1 \mathrm{~mm}$ GABA had rapid rates of rise $\left(t_{10-90 \%}=1.2 \pm 0.1 \mathrm{msec}\right)$ and had decay phases that were typically best described by three exponential components (Fig. 1, Table 1). Weighted time constants $\left(\tau_{\text {Decay }}\right)$ of the responses of excised and nucleated patches to $1 \mathrm{~mm}$ GABA were indistinguishable (Student's $t$ test; $p>0.3$ ), and were grouped for subsequent analyses. Decay kinetics of responses to 1 versus $10 \mathrm{~mm}$ GABA were also not significantly different $\left(1 \mathrm{~mm}: \tau_{\text {Decay }}=63.9 \pm 2.6 \mathrm{msec}, n=52 ; 10 \mathrm{~mm}: 66.6 \pm\right.$ $6.3 \mathrm{msec}, n=14 ; p>0.3$, Student's $t$ test).

These "simulated IPSCs" had substantially different time courses from whole-cell spontaneous IPSCs. Rise times of IPSCs $(0.9 \pm 0.1 \mathrm{msec})$ were shorter than those of patch responses $(p<$ $10^{-5}$; Student's $t$ test). Decays of IPSCs were typically best described by a sum of two exponential components (Table 1), with rates comparable to the two fastest decay components in the patch responses (Fig. $2 A$ ). In 12 cells, we directly compared these rates by recording spontaneous IPSCs in the intact cell and rapid application responses after patch excision. Decay kinetics were approximately fourfold slower for patch responses than for whole-cell (WC) IPSCs in these cells (WC IPSC, $\tau_{\text {Decay }}=17.9 \pm$ $1.1 \mathrm{msec}$; patch response: $\tau_{\text {Decay }}=70.4 \pm 3.9 \mathrm{msec} ; p<10^{-7}$, paired Student's $t$ test) (Fig. $2 B$ ). The fastest decay component $\left(\tau_{\text {Dec }, 1} \sim 10 \mathrm{msec}\right)$ was not significantly different between wholecell and patch responses ( $p>0.5$; paired Student's $t$ test), whereas the amplitude of this component and the rate and amplitude of the second component were significantly different ( $p<$ 0.01 ). We will present evidence below that the rapid decay component of the patch responses likely represents the contribution of synaptic receptors to this response, whereas the second decay component of the patch responses represents the comingling of fast synaptic and slow extrasynaptic receptors. Contrary to the population as a whole, rise times in these twelve cells were not significantly different for synaptic versus patch responses (WC, $0.9 \pm 0.1 \mathrm{msec}$; patch, $1.1 \pm 0.1 \mathrm{msec} ; p>0.2$ ).

Possible reasons for the observed difference in kinetics fall into two general categories: (1) factors external to the patch, such as the transmitter transient and extracellular modulatory agents, and (2) factors intrinsic to the patch, such as the isomerization kinetics of the receptors. 

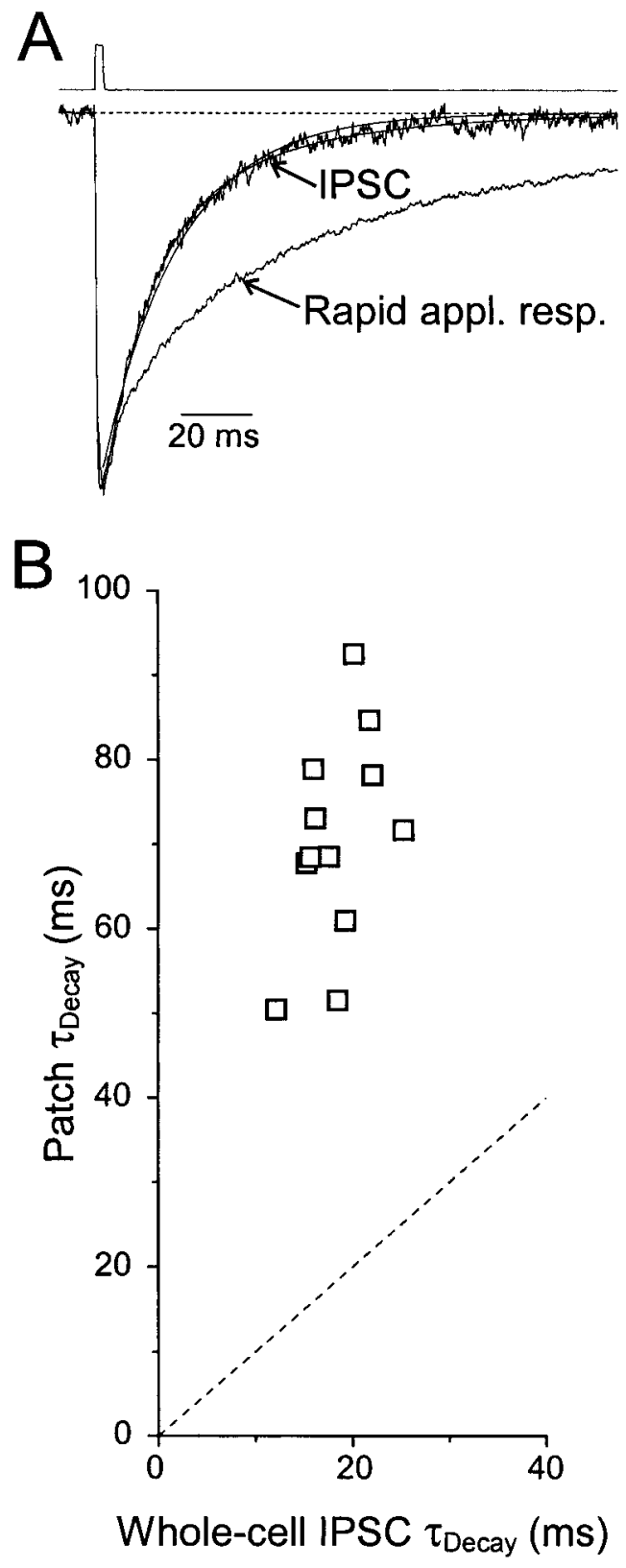

Figure 2. IPSCs and patch responses have different decay kinetics. $A$, Normalized average spontaneous IPSC and rapid application response to $1 \mathrm{~mm}$ GABA in an excised patch recorded from the same cell before and after patch excision. For the IPSC, biexponential fit parameters were $\tau_{\text {Dec1,2 }}=13.1(68 \%)$ and $41.4 \mathrm{msec}$; monoexponential fit parameter was $\tau_{\text {Dec }}=22.0 \mathrm{msec}$. For the patch response, triexponential fit parameters were $\tau_{\text {Dec1.3. }}=11.6(30 \%), 69.3(55 \%)$, and 244 msec. Top trace shows the open-tip junction current recorded immediately after terminating the recording. $B$, Decay kinetics of rapid application responses plotted versus decay kinetics of IPSCs recorded in the same cells before patch formation. Dotted line has unity slope. In these 12 cells, fit parameters for the whole-cell IPSCs were $\tau_{\text {Dec1,2 }}=11.7 \pm 1(63 \pm 1 \%)$ and $31.6 \pm 2.6 \mathrm{msec}$. Fit parameters for the rapid application responses were $\tau_{\mathrm{Dec} 1,2,3}=9.7 \pm$ $1.6(16 \pm 3 \%), 54.9 \pm 2.8(63 \pm 4 \%)$, and $168 \pm 11 \mathrm{msec}$.

\section{Influence of transmitter concentration and time course on $\tau_{\text {decay }}$}

The deactivation of $\mathrm{GABA}_{\mathrm{A}}$ receptors after brief exposure to ligand is a complex process involving entry and exit from open, bound, and desensitized states of both singly and doubly liganded

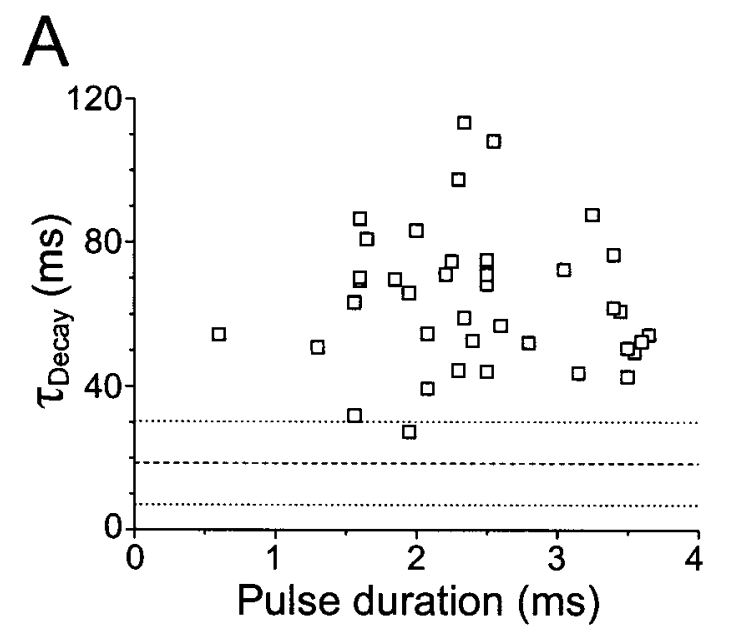

B

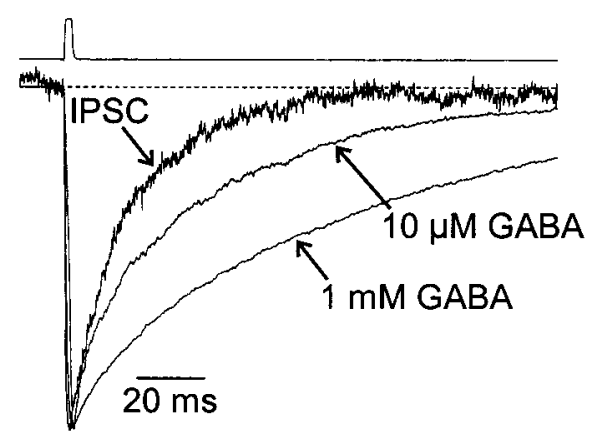

Figure 3. Effect of transmitter duration and concentration on decay kinetics. $A$, Decay time constants of rapid application responses of excised patches versus the duration of the GABA pulses $(1 \mathrm{mM})$. Dashed and dotted lines represent the mean $\pm 2 \mathrm{SD} \tau_{\text {Decay }}$ for whole-cell IPSCs. $B$, Normalized average spontaneous IPSC and rapid application response to $10 \mu \mathrm{M}$ and $1 \mathrm{~mm}$ GABA recorded from the same cell before and after formation of a nucleated patch. For the IPSC, $\tau_{\mathrm{Dec} 1,2}=13.4(74 \%)$ and $39.4 \mathrm{msec}$. For the $10 \mu \mathrm{M}$ patch response, $\tau_{\mathrm{Dec} 1,2,3}=4.67(20 \%), 34.7$ $(61 \%)$, and $115 \mathrm{msec}$. For the $1 \mathrm{~mm}$ patch response, $\tau_{\text {Dec1,2,3 }}=9.8(12 \%)$, 66.1 (57\%), and $173 \mathrm{msec}$. Top trace shows the open-tip junction current recorded immediately after terminating the recording.

receptors (Jones and Westbrook, 1995). The rates of transitions between these states, together with the duration and peak concentration of the transmitter transient, determine to what extent each of these states is visited during, and after, ligand exposure. Monoliganded receptors generate much briefer and less frequent openings than doubly liganded receptors, presumably because of slow entry into and rapid exit from the monoliganded open state (Macdonald et al., 1989). Thus, brief transients and/or low agonist concentrations may result in smaller responses and more rapid return of receptors to their resting state after agonist exposure if the binding rate is slow enough to produce a high percentage of monoliganded receptors compared to doubly liganded receptors. This may be relevant to synaptic $\mathrm{GABA}_{\mathrm{A}}$ responses, because some studies have shown that IPSCs are generated by subsaturating transmitter transients (Frerking et al., 1995; Nusser et al., 1997).

We saw no correlation between decay time course and pulse duration for pulses between 0.6 and $3.7 \mathrm{msec}(r=0.08 ; p>0.6)$ (Fig. $3 A$ ), indicating that for $1 \mathrm{~mm}$ GABA, the binding rate remains large compared to even the briefest pulses that we delivered, so that doubly liganded receptor responses must still 
dominate the decay. This is consistent with estimates of the binding rate of GABA to the $\mathrm{GABA}_{\mathrm{A}}$ receptor of $5.38 \mathrm{~mm}^{-1}$ $\mathrm{msec}^{-1}$ (Jones et al., 1998), which yields a binding time constant of $186 \mu \mathrm{sec}$ for $1 \mathrm{~mm}$ GABA. Although we were unable to reliably deliver pulses briefer than several hundred microseconds, we could equivalently test the decay kinetics of monoliganded receptors by using $2 \mathrm{msec}$ pulses of $10 \mu \mathrm{M}$ GABA. At this concentration, the pulse duration is approximately nine times briefer than the binding time constant and three times briefer than the unbinding time constant, and thus the vast majority of bound receptors will be monoliganded. Responses of nucleated patches to 2 msec pulses of $10 \mu \mathrm{M}$ GABA had amplitudes that were $4.2 \%$ of the responses to $1 \mathrm{~mm}$ GABA $(10 \mu \mathrm{M}: 287 \pm 97 \mathrm{pA}, n=6 ; 1 \mathrm{~mm}$ : $6850 \pm 532 \mathrm{pA}, n=25)$. These responses decayed more rapidly than responses to $1 \mathrm{~mm}$ GABA (Fig. $3 B$, Table 1), primarily because of a prominent, rapid initial decay phase. However, this initial decay component was approximately twice as fast as the initial IPSC decay component, and these responses were still substantially slower than the decays of IPSCs $(p<0.005)$ because of a prolonged tail with time constant $>100 \mathrm{msec}$. Responses to $2 \mathrm{msec}$ pulses of $30 \mu \mathrm{M}$ GABA had amplitudes that were $10.7 \%$ of the response to $1 \mathrm{~mm} \mathrm{GABA}(731 \pm 267 \mathrm{pA} ; n=$ 4 ) and intermediate decay kinetics (Table 1). These results indicate that differences between synaptic and exogenous transmitter transients in time course and concentration are unable to account for the observed differences in $\tau_{\text {Decay }}$.

\section{Effects of $\mathrm{Zn}^{2+}, \mathrm{pH}$, and pre-equilibration with GABA on patch deactivation kinetics}

The deactivation time course of synaptic $\mathrm{GABA}_{\mathrm{A}}$ receptors could also be affected by cofactors released with GABA or continuously present in the extracellular milieu. Both $\mathrm{Zn}^{2+}$ and $\mathrm{H}^{+}$ions have been shown to modulate the amplitude and kinetics of $\mathrm{GABA}_{\mathrm{A}}$ receptor-mediated currents (Westbrook and Mayer, 1987; Krishek et al., 1996; Berger et al., 1998; Gingrich and Burkat, 1998). If these cofactors are released with GABA at the synaptic cleft (Assaf and Chung, 1984; Miesenbock et al., 1998), it is possible that they could contribute to the rapid decay kinetics of synaptic responses. We tested this hypothesis by coapplying either $\mathrm{H}^{+}(1 \mu \mathrm{M}$, i.e., 16-fold higher concentration than control) or $\mathrm{Zn}^{2+}(300 \mu \mathrm{M})$ with $1 \mathrm{~mm}$ GABA to outside-out patches. (By "coapplication", we mean that the cofactors were present only when GABA was present.) Raising $\left[\mathrm{H}^{+}\right]$to $1 \mu \mathrm{M}$ resulted in only a small $(\sim 11 \%)$ decrease in $\tau_{\text {Decay }}$ and an increase in peak amplitude by $\sim 12 \%$ ( $n=3 ; p<0.05$, paired Student's $t$ test). Coapplication of $\mathrm{Zn}^{2+}$ had no effect on either deactivation kinetics or peak amplitude $(n=3 ; p>0.5$; Student's $t$ test $)$, suggesting that corelease of $\mathrm{Zn}^{2+}$ or $\mathrm{H}^{+}$is unlikely to explain the approximately threefold difference in decay kinetics between patch and synaptic responses. We also continuously bathed outside-out patches in $10 \mu \mathrm{M} \mathrm{Zn}^{2+}$ to assess the effect of low levels of extracellular $\mathrm{Zn}^{2+}$ on receptor kinetics. In two patches, $\tau_{\text {Decay }}$ was reduced by 20 and $30 \%$, less than the $70 \%$ reduction required to explain the kinetic difference between synaptic and rapid application responses. Peak amplitudes were reduced by 15 and $25 \%$, respectively, in these two patches.

The time course of relaxation of the receptor population back to its resting state after exposure to ligand will depend in part on the distribution of receptors in the available states immediately before the agonist pulse. GABA is present in the extracellular space of the hippocampus at submicromolar concentrations (Lerma et al., 1986; Tossman et al., 1986) and, thus, some recep- tors will be bound by GABA at any given moment in time. We tested the effects of pre-equilibration of synaptic receptors with micromolar levels of GABA by exposing excised and nucleated receptors to low concentrations of GABA for several seconds to several minutes before applying $1 \mathrm{~mm}$ GABA for $2 \mathrm{msec}$. GABA applied at a concentration of $1 \mu \mathrm{M}$ had no measurable effect on $\tau_{\text {Decay }}$ of the brief pulse responses $(n=3 ; p>0.4$; paired Student's $t$ test), although it did reduce slightly the amplitude of the response by $<10 \%$. Thus, pre-equilibration cannot account for the difference between patch and synaptic responses.

\section{Responses of excised patches to synaptically released transmitter}

Although none of the presynaptic or extracellular factors that we tested caused the decay times of brief-pulse rapid application responses to be comparable to IPSCs, it is possible that some other untested modulator, cofactor, or transmitter is present in the slice. To test the responses of excised receptors in their native environment, we exposed excised patches to synaptically released transmitter, with any attendant cofactors and extracellular modulatory agents, by reinserting the excised patch back into stratum pyramidale to act as a sniffer patch (Isaacson et al., 1993) and electrically evoking synaptic release in the presence of CNQX and APV. We then compared these responses with whole-cell evoked synaptic responses recorded immediately before patch excision and to rapid application responses in other patches.

Sniffer patch responses evoked by stimuli in stratum pyramidale were variable in amplitude and time course (Fig. 4). When patches were held above the slice, out of the tissue, no response could be measured (Fig. 4A). When inserted into the slice, response amplitude was a sensitive function of position, presumably reflecting variable proximity to release sites. Small amplitude responses typically had slower rise times and longer latencies (Fig. 4A), consistent with diffusion of GABA from a remote release site to the sniffer patch. Small changes in the position of the sniffer patch could result in much larger amplitude responses with faster rise times (Fig. $4 A-C$ ). Unlike the effect on rise time and amplitude, proximity to the release site had little impact on current decay (Fig. 4B), suggesting that details of the time course or peak concentration of the transmitter transient were not the primary factors in determining decay kinetics.

In four cases, we were able to position the sniffer patches close enough to the presynaptic terminals to generate responses with rise times $<2 \mathrm{msec}(1.6 \pm 0.1 \mathrm{msec})$, i.e., within the range of the rapid application responses observed with other patches (Fig. 5). These rapid rise times most likely reflect the brief duration of the transmitter transient eliciting the sniffer patch response. The amplitudes of these responses averaged $>250$ pA (range, 48.1$695 \mathrm{pA})$. Decay times of these sniffer patch responses were significantly slower than those of IPSC decays $(67.0 \pm 2.7 \mathrm{vs}$ $19.4 \pm 1.3 \mathrm{msec} ; p<10^{-3}$, paired Student's $t$ test), but were not significantly different from rapid application responses of excised receptors to brief pulses of GABA ( $p>0.4$; Fig. $5 A, B)$.

Although the rapid rise times of these sniffer patch responses are indicative that they were exposed to a brief, high concentration pulse of transmitter, we considered the possibility that the prolonged decay of the response is attributable to the extended presence of a low concentration of transmitter in the extrasynaptic space and that the rapid decay kinetics of IPSCs represents the intrinsic deactivation kinetics of the receptors in the absence of a prolonged, low-concentration GABA "tail". In this case, the farther the sniffer patch is from the synaptic cleft, the slower its 

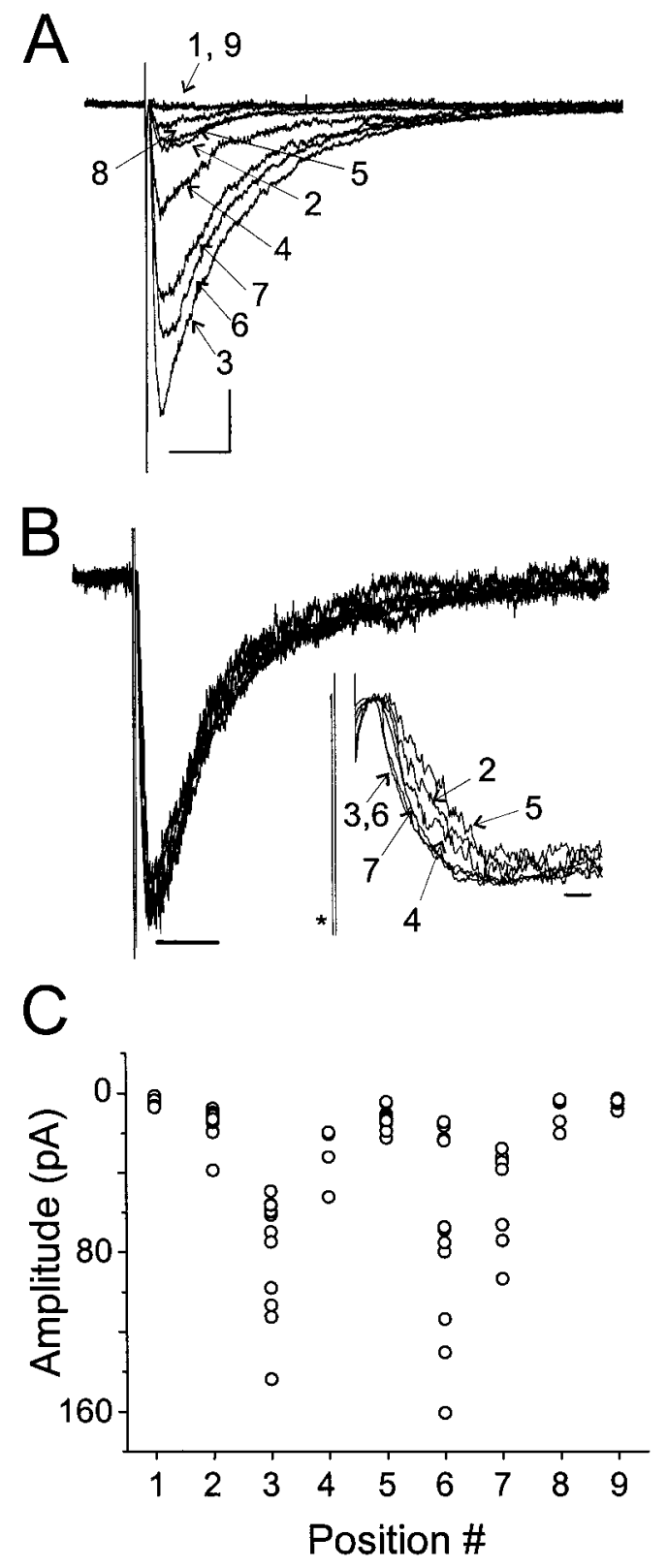

Figure 4. Responses of excised sniffer patches to synaptically released transmitter. $A$, Sniffer patch responses to stimuli in stratum pyramidale. Shown are the averaged responses at nine different positions, indicated by numbers, above and in the slice. Positions 1 and 9 were above the slice. Positions 3 and 6 were the same location and yielded the largest amplitude responses. Position 2 was $10 \mu \mathrm{m}$ from 3 , whereas positions $4,5,7$, and 8 were $3,6,10$, and $20 \mu \mathrm{m}$ from position 3 , respectively, in the opposite direction as position 2 . Calibration: $15 \mathrm{pA}, 20 \mathrm{msec}$. $B$, Normalized data from $A$. Note that the decay kinetics exhibit little dependence on position. Calibration: $50 \mathrm{msec}$. Inset shows the normalized traces. Note the change in latency and rise time as position was changed. Asterisk marks the stimulus artifact. Trace from position 8 had a high noise level and is not shown. Calibration: $2 \mathrm{msec}$. $C$, Peak amplitude as a function of position for individual responses from the positions shown in $A$ and $B$. Note that although the response amplitudes were variable, there were abrupt changes in the amplitude range as a function of position.

decay kinetics should be. However, when the data from sniffer patch responses with rapid rise times were compared with those from slowly rising responses (range, 3.9-9.9 msec), we found no correlation between rise time and decay time, even though the proximity to the release site (and thus the transmitter transient) was undoubtedly quite variable between patches (Fig. 5C). Thus, the sniffer patch data indicate that the slow decay rate of patch responses is governed primarily by the intrinsic properties of the receptors in the patch, rather than presynaptic or extracellular factors such as the time course of the transmitter transient, the presence of cotransmitters, or of modulatory factors.

\section{Properties of IPSCs recorded in nucleated patches}

There are two scenarios in which postsynaptic factors could explain the kinetic differences between IPSCs and patch responses: (1) the receptors mediating patch responses to exogenous GABA pulses are synaptic receptors whose properties have been altered following patch excision; (2) synaptic receptors compose only a subset of the receptors that mediate patch responses, with the remainder comprised of extrasynaptic receptors with slower kinetics. Although it might seem likely that the process of excising $\mathrm{GABA}_{\mathrm{A}}$ receptors from their native environment might itself alter their kinetic properties, this did not appear to be the case. We observed that after forming nucleated patches and lifting them 2-3 $\mathrm{mm}$ above the slice, spontaneous IPSCs could still be recorded in $\sim 20 \%$ of the patches (Fig. $6 A, B$ ). These events most likely arose from spontaneous release of transmitter from synaptic terminals that remained anchored to the postsynaptic membrane. These "nucleated patch IPSCs" had kinetics that were similar to IPSCs recorded in the intact cells [patch: $t_{10-90 \%}=0.8 \pm 0.1 \mathrm{msec}, \tau_{\mathrm{Dec} 1,2}=10.3 \pm 1.3(60 \pm 10 \%)$ and $36.6 \pm 2.9$ msec; whole-cell: $t_{10-90 \%}=0.9 \pm 0.1 \mathrm{msec}, \tau_{\text {Dec } 1,2}=$ $11.9 \pm 0.8(70 \pm 10 \%)$ and $30.6 \pm 2.2 \mathrm{msec} ; p>0.1$ for all fit parameters by paired Student's $t$ test] (Fig. 6C,D, Table 2), suggesting that the process of establishing a nucleated patch does not alter the determinants of deactivation kinetics of synaptic receptors. The amplitudes of nucleated patch IPSCs were also similar to the amplitudes of spontaneous IPSCs recorded in intact cells (whole-cell, $71.7 \pm 15.2 \mathrm{pA}$; patch, $71.1 \pm 29.2 \mathrm{pA} ; n=10$ cells; $p>0.9$, paired Student's $t$ test), providing evidence that the peak open probability of synaptic receptors is also not altered by patch excision. In four cells, sufficient numbers of spontaneous IPSCs were recorded in nucleated patches to analyze the variability of IPSC amplitude and $\tau_{\text {Decay }}$ (Fig. $6 E, F$, Table 2). There were no consistent differences in the coefficient of variation of amplitudes or the SD of $\tau_{\text {Decay }}$, indicating that nucleated patch IPSCs do not consist of responses of a mixed population of damaged and undamaged postsynaptic receptors.

\section{Coexistence of two receptor classes in nucleated patches}

Although nucleated patch IPSCs show that the kinetics of synaptic receptors are not altered by patch excision, we sought direct evidence that two kinetic classes of $\mathrm{GABA}_{\mathrm{A}}$ receptors coexist in the same nucleated patch by subsequently exposing these same nucleated patches to exogenous GABA pulses. Rapid application responses were markedly prolonged relative to nucleated patch IPSCs [nucleated patch IPSC: $\tau_{\text {Dec }}=15.2 \pm 2.5 \mathrm{msec}$; rapid application response ( $1 \mathrm{~mm}, 2 \mathrm{msec}$ GABA $): \tau_{\text {Dec }}=76.6 \pm 10.3$ msec; $n=4$ patches; $p<0.005$ paired Student's $t$ test] (Fig. 7A). These results demonstrate directly the presence of two kinetic classes of receptors in these patches.

The similarity between whole-cell and nucleated sIPSCs (Fig. 6) demonstrates that the kinetic properties of synaptic receptors are unchanged in patches. It follows then that a large proportion of receptors mediating responses to exogenous GABA pulses 
A
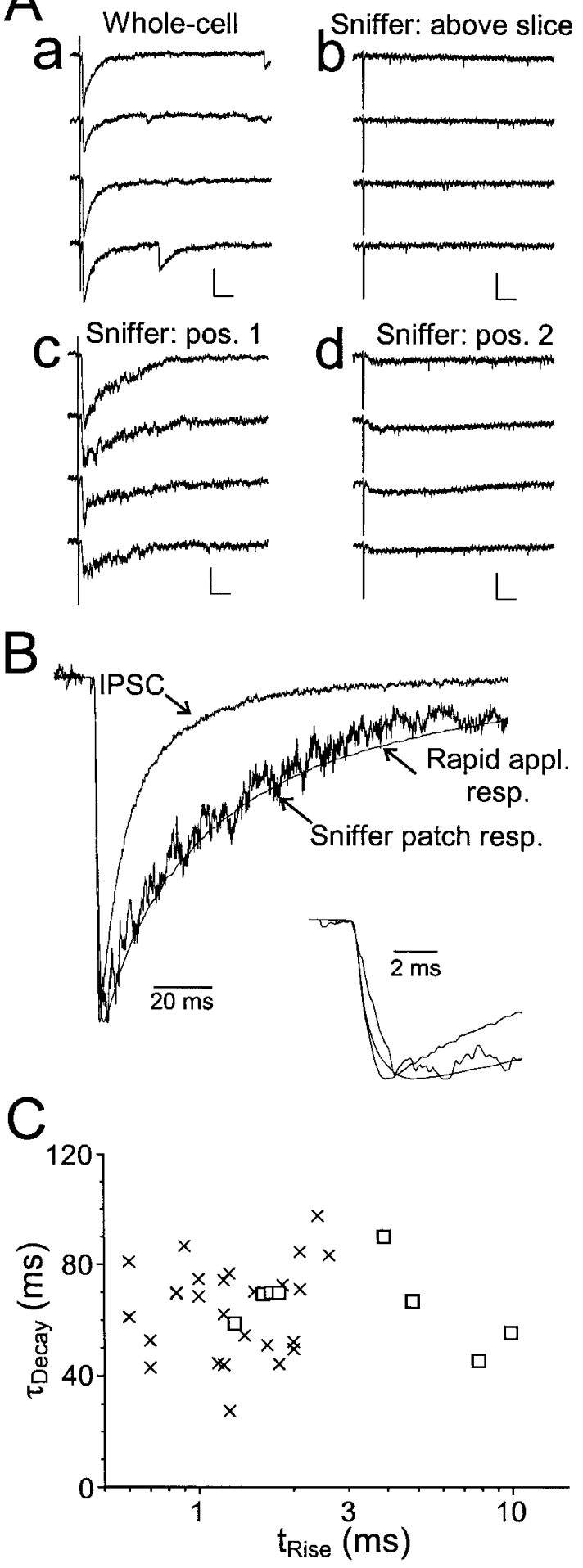

Figure 5. Comparison of sniffer patch and whole-cell synaptic responses. $A$, Raw traces recorded in response to stimuli applied to stratum pyramidale. $a$, Whole-cell IPSCs. $b$, Sniffer patch data recorded from an excised patch placed above the slice. Note that in this position, no response was evoked by the stratum pyramidale stimulus. $c$, Response of the same patch to the same stimulus, but recorded after placing the recording electrode tip on a pyramidal cell body. $d$, Response to the same stimulus after moving the recording electrode $\sim 5 \mu \mathrm{m}$ away from the cell body. Distance was gauged using the tip diameter of the patch pipette, which was typically 2-3 $\mu \mathrm{m}$. Calibration bars: $a, 100 \mathrm{pA}, 20 \mathrm{msec} ; b, 25 \mathrm{pA}, 20$ msec. $B$, Normalized averaged traces from the data shown in $A a$ and $A c$. Inset shows the same data on an expanded time scale. For the IPSC, $t_{\text {Rise }}=0.7$ must arise from receptors whose kinetics are slow relative to synaptic receptors (i.e., extrasynaptic), and that the amplitude of responses to exogenous GABA pulses should exceed the amplitude that would be generated by synaptic receptors alone. To determine whether this is the case, we compared the responses of nucleated patches to exogenously applied GABA with the amplitude that would be expected if these responses were mediated only by synaptic receptors. We used miniature (action-potential independent) IPSC (mIPSC) amplitude as a measure of the response amplitude at a single synapse and found that mIPSC amplitudes averaged $39.1 \pm 2.0 \mathrm{pA}$ at $-60 \mathrm{mV}(n=32$ cells $)$. By multiplying by the density of inhibitory synapses on the somata of CA1 pyramidal cells $\left(0.2 \pm 0.02\right.$ synapses $/ \mu \mathrm{m}^{2} ; n=5$ cells; M. Megías, Z. Emri, T. F. Freund, and A. I. Gulyás, personal communication), by the somatic surface area $\left(520 \mu \mathrm{m}^{2}\right.$; see Materials and Methods), and by the ratio of surface area in the nucleated patch to that in the intact soma (0.36; see Materials and Methods), the maximal response amplitude of synaptic receptors can then be calculated to be $1464 \mathrm{pA}$ if saturation of synaptic receptors is achieved. This response amplitude is indeed smaller than what we observed in response to $1 \mathrm{~mm}$ GABA $(6850 \mathrm{pA})$.

\section{Differences in calcium modulation between synaptic and extrasynaptic receptors}

In addition to differences in deactivation kinetics, we found that synaptic and extrasynaptic receptors also differ in their modulation by elevated cytoplasmic levels of calcium. The pipette solution used for all of the experiments described above contained 10 mM BAPTA. Using a calcium-sensitive electrode, we measured the free calcium concentration in this pipette solution to be $\sim 20$ nM. When BAPTA was omitted from the pipette solution, free calcium levels were $>2 \mu \mathrm{M}$ with 0 added calcium, presumably because of contaminants present in other salts. Elevated calcium levels significantly decreased the decay times of rapid application responses $\left(\tau_{\text {Decay }}=27.7 \pm 3.8 \mathrm{msec} ; n=11\right)$ (Fig. 7) when compared with $10 \mathrm{~mm}$ BAPTA responses $\left(p<10^{-6}\right.$, Student's $t$ test). These data demonstrate that it is possible to record rapid responses to GABA in outside-out patches and thus that the slow decay kinetics of rapid application responses under control conditions is not the result of some unidentified artifact of the technique.

In three patches recorded with 0 BAPTA, patch IPSCs could also be observed. In contrast to the rapid application responses of these patches, the decay times of these synaptic responses $(24.3 \pm$ $3.5 \mathrm{msec}$ ) appeared to be unaffected by elevated calcium, because they were not significantly different from patch IPSCs recorded in the presence of $10 \mathrm{~mm}$ BAPTA ( $p>0.4$; Student's $t$ test) (Fig. $7 B, C)$. The selective modulation of patch responses to exogenous transmitter application by elevated cytoplasmic calcium is further evidence that the sets of receptors that mediate synaptic responses and rapid application responses are not the same and is consistent with the hypothesis that rapid application responses are dominated by extrasynaptic receptors. This selective modu-

$\leftarrow$

msec, $\tau_{\text {Decay }}=16.0 \mathrm{msec}$. For the sniffer patch response, $t_{\text {Rise }}=1.7 \mathrm{msec}$, $\tau_{\text {Decay }}=69.9 \mathrm{msec}$. Also shown is the averaged rapid application response from all excised patches. $C$, Weighted decay time constant versus rise time plotted for eight sniffer patch responses (squares) and for excised patch responses (crosses). Note that there is no correlation between rise time and decay time for the sniffer patch data. Note also that the responses from four of the sniffer patches fall within the range of rise times recorded from excised patches. 


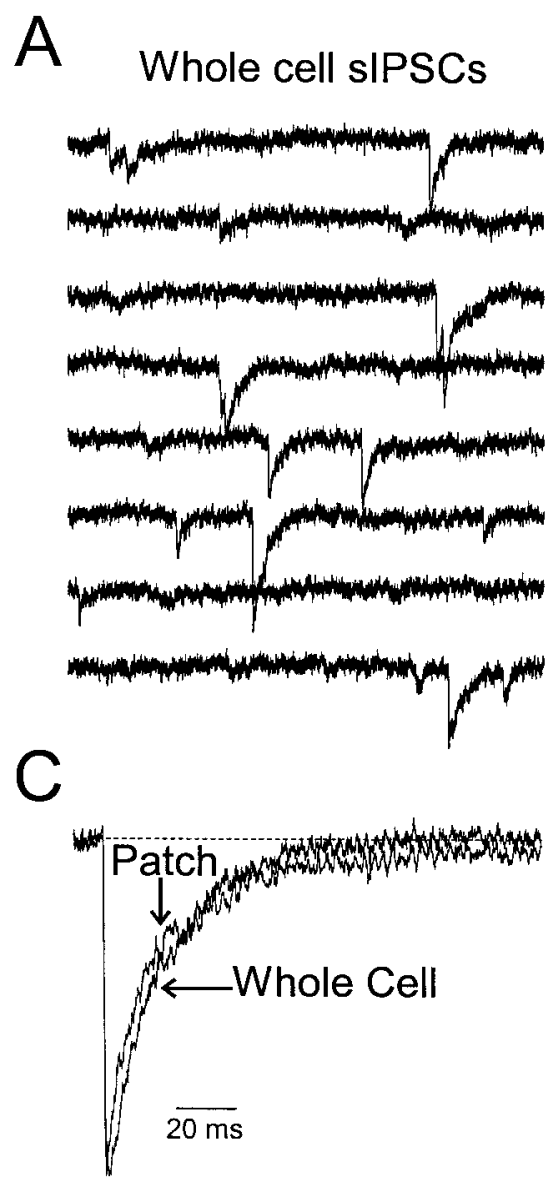

Figure 6. Properties of spontaneous IPSCs recorded in nucleated patches. $A$, Whole-cell sIPSCs recorded before patch excision. Traces are consecutive. This cell corresponds to cell 1 in Table 2. B, sIPSCs recorded from a nucleated patch after removal from the slice. Traces are not consecutive and represent all of the spontaneous events recorded over an $80 \mathrm{sec}$ period. $C$, Normalized averaged sI PSCs from the cell in $A$ and $B$. Biexponential fits were: whole-cell, $\tau_{\text {Dec } 1,2}=$ $9.9(47 \%)$ and $27.8 \mathrm{msec}$; patch, $\tau_{\mathrm{Dec} 1,2}=6.1$ $(47 \%)$ and $32.8 \mathrm{msec} . D$, Patch IPSC weighted time constant versus whole-cell IPSC weighted time constant for 10 cells. There was no significant difference in mean $\tau_{\text {Decay }}$ between the patch and whole-cell data $(p=0.2$, paired Student's $t$ test). $E$, Cumulative amplitude distribution for spontaneous IPSCs recorded in the same cell as in $A-C$ in whole-cell (thin line) and nucleated patch (thick line). Inset shows normalized amplitude distributions. $F$, Same as $E$, but for $\tau_{\text {Decay. }}$.

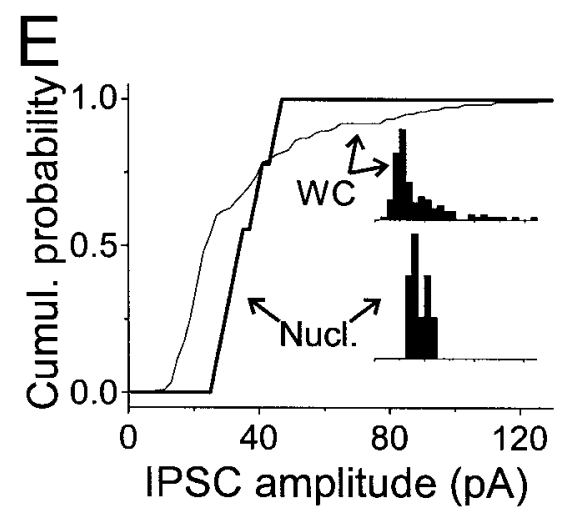

B

Nucl. patch sIPSCs
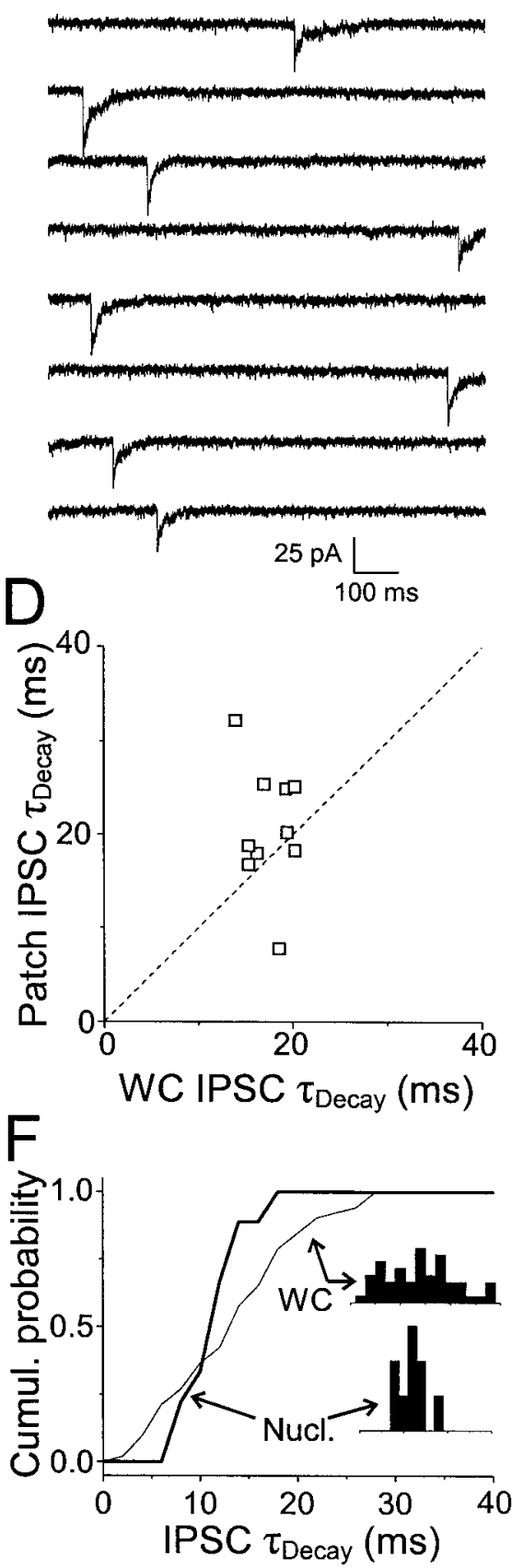

lation may also be a manifestation of the regulatory mechanism that is the basis of the difference in receptor kinetics in the intact cells.

\section{DISCUSSION}

The main findings of this study are that neither presynaptic factors (transmitter transient, the presence of extracellular modulatory agents), nor alteration of receptors by patch excision can account for kinetic differences between synaptic and excised patch responses. We conclude that extrasynaptic receptors dominate patch responses and that these receptors have slower intrinsic kinetics than synaptic receptors.

\section{Sniffer patch responses}

To assess whether an untested cotransmitter or extracellular modulator underlies the rapid decays of IPSCs, we measured the responses of $\mathrm{GABA}_{\mathrm{A}}$ receptors in excised patches to synaptically released transmitter. Decay kinetics of these sniffer patch responses were similar to those in response to exogenous GABA pulses, indicating that the kinetic differences between IPSCs and exogenous application responses lie in the receptors themselves. One caveat to this conclusion is that low concentrations of lowaffinity agonists such as taurine or $\beta$-alanine, which produce rapid deactivation (Jones et al., 1998), may be difficult to detect with 
Table 2. Amplitude and kinetic parameters for whole-cell and nucleated patch spontaneous IPSCs

\begin{tabular}{|c|c|c|c|c|c|c|c|c|c|c|c|c|}
\hline & \multicolumn{6}{|c|}{ Whole-cell IPSCs } & \multicolumn{6}{|c|}{ Nucleated patch IPSCs } \\
\hline & $\begin{array}{l}\text { Amp } \\
(\mathrm{pA})\end{array}$ & $\mathrm{CV}_{\mathrm{Amp}}$ & $\begin{array}{l}\tau_{\text {Decay }} \\
(\mathrm{msec})\end{array}$ & $\sigma_{\tau}$ & $\begin{array}{l}t_{\text {Rise }} \\
(\mathrm{msec})\end{array}$ & $n$ & $\begin{array}{l}\text { Amp } \\
(\mathrm{pA})\end{array}$ & $\mathrm{CV}_{\mathrm{Amp}}$ & $\begin{array}{l}\tau_{\text {Decay }} \\
(\mathrm{msec})\end{array}$ & $\sigma_{\tau}$ & $\begin{array}{l}t_{\text {Rise }} \\
(\mathrm{msec})\end{array}$ & $n$ \\
\hline Cell \#1 & 33.9 & 0.66 & 19.4 & 6.9 & 0.7 & 121 & 36.2 & 0.19 & 20.3 & 3.2 & 0.6 & 9 \\
\hline Cell \#2 & 54.3 & 1.11 & 14.7 & 5.1 & 0.6 & 369 & 144.8 & 1.26 & 17.1 & 7.6 & 0.8 & 39 \\
\hline Cell \#3 & 56.3 & 0.88 & 11.4 & 3.9 & 1.2 & 1711 & 93.2 & 1.01 & 14.4 & 7.1 & 1.0 & 27 \\
\hline Cell \#4 & 41.3 & 0.65 & 17.2 & 6.9 & 0.7 & 129 & 27.8 & 0.44 & 17.1 & 6.8 & 0.7 & 28 \\
\hline
\end{tabular}

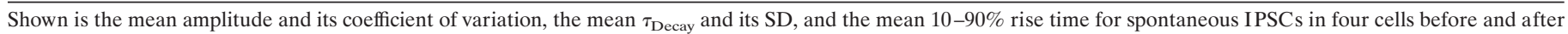
the formation of a nucleated patch and its removal from the slice. $n$ is the number of IPSCs.

sniffer patches outside the synaptic cleft. However, for a lowaffinity cotransmitter to produce rapidly decaying IPSCs, it would have to prevent nearly all synaptic receptors from binding two GABA molecules, as we have shown that receptors fully liganded by GABA have slow deactivation kinetics. Because a low-affinity agonist such as $\beta$-alanine has a binding rate that is $>200$-fold slower than GABA (Jones et al., 1998), in this scenario it would have to be present at $>1000$-fold higher concentration than GABA. The possibility that a cotransmitter would be released at such high concentrations and would remain undetected by the sniffer patches is remote.

\section{Kinetics of synaptic versus extrasynaptic receptors}

One explanation for kinetic differences between synaptic and extrasynaptic receptors is subunit composition (Verdoorn, 1994; Gingrich et al., 1995; Tia et al., 1996b; McClellan and Twyman, 1999). Extrasynaptic receptors in immature cerebellar granule cells are composed solely of $\alpha$ and $\beta$ subunits, whereas the composition of synaptic receptors is $\alpha \beta \gamma$ (Brickley et al., 1999). Consistent with this, $\gamma$ subunits are required for clustering at synapses, and receptors composed exclusively of $\alpha$ and $\beta$ subunits are diffusely distributed in the plasma membrane (Essrich et al., 1998). It may be possible that the subunit compositions of synaptic versus extrasynaptic receptors are similarly distinguished in hippocampus. However, the presence or absence of $\gamma_{2}$ subunits in $\alpha_{1} \beta_{2}$ - and $\alpha_{6} \beta_{2}$-containing receptors has little effect on deactivation kinetics (Tia et al., 1996b), and so differences in $\alpha$ or $\beta$ subunits may better explain the slower kinetics of extrasynaptic receptors. For example, in human embryonic kidney cells expressing $\alpha_{\mathrm{x}} \beta_{1} \gamma_{2}$ receptors, substituting $\alpha_{2}$ - for $\alpha_{1}$-containing receptors changes the $\tau_{\text {Decay }}$ of patch responses from 18 to $50-80 \mathrm{msec}$ (McClellan and Twyman, 1999), similar to difference between IPSCs and rapid application responses in our data.

An alternative possibility is that synaptic and extrasynaptic receptors are regulated differently by second messenger systems, as suggested by our results with 0 BAPTA. Elevated $[\mathrm{Ca}]_{\mathrm{i}}$ modulates affinity and kinetics of $\mathrm{GABA}_{\mathrm{A}}$ receptors (Inoue et al., 1986; Chen et al., 1990; Martina et al., 1994; Stelzer and Shi, 1994; Mozrzymas and Cherubini, 1998), often by activation of kinases or phosphatases. In cultured hippocampal neurons, $\tau_{\text {Decay }}$ of synaptic and exogenous GABA responses is regulated by the calcium-dependent phosphatase calcineurin and by unknown kinases (Jones and Westbrook, 1997). In these cells, maximally phosphorylated $\mathrm{GABA}_{\mathrm{A}}$ receptors produced responses that were approximately twice as fast as under control conditions, although IPSCs were still much slower than in hippocampal slices. Despite these quantitative differences, this suggests that in our experiments synaptic receptors may be more fully phosphorylated than extrasynaptic receptors. In this scenario, elevated [Ca] in nucle- ated patches from slices may activate calcium-dependent kinases that phosphorylate extrasynaptic receptors but have no effect on synaptic receptors because they are already maximally phosphorylated. This suggestion is consistent with a recent study that found that activation of kinases had little effect on the overall decay kinetics of IPSCs in CA1 pyramidal cells (Poisbeau et al., 1999).

\section{Relative density of synaptic versus extrasynaptic receptors}

We calculated that synaptic receptors contributed $\sim 25 \%$ of the rapid application response, assuming that synaptic receptors are saturated. Their contribution will be higher, however, if the peak cleft concentration is lower. We know from the sniffer patch data that the concentration is at least high enough to generate $\sim 45 \%$ of the response to $1 \mathrm{~mm}$ GABA. (Note that this comparison is between different groups of patches, albeit pulled with the same size pipettes and same technique. Sniffer patches were not calibrated using rapid application of GABA.) If the peak transmitter concentration in the cleft is this low, the contribution of synaptic receptors in nucleated patches to $1 \mathrm{~mm}$ GABA may be as high as $3250 \mathrm{pA}$. Assuming that peak open probability and single-channel conductance of synaptic and extrasynaptic receptors are the same, synaptic receptors account for $21-47 \%$ of the patch response (i.e., $1464-3250$ of $6850 \mathrm{pA})$.

We can corroborate this estimate using the deactivation kinetics of patch responses. The triphasic responses of excised and nucleated patches to exogenous GABA pulses most likely reflect the commingling of synaptic receptors (with time constants of $\sim 10$ and $30 \mathrm{msec}$ ) with slower extrasynaptic receptors. The fastest decay component $(\sim 14 \mathrm{msec})$ in patch responses accounted for $25 \%$ of the total response amplitude. If this component represents only synaptic receptors, then their maximum contribution to the patch response can be calculated by dividing this amplitude by the amplitude of the fast decay component in IPSCs. This estimate indicates that $>60 \%$ of the patch response is generated by extrasynaptic receptors, within the range calculated above. The calculated percentages of synaptic versus extrasynaptic receptor contributions will only translate into relative numbers of receptors if peak open probabilities and the single-channel conductances of the two receptor populations are the same.

Although extrasynaptic $\mathrm{GABA}_{\mathrm{A}}$ receptors have been observed previously using immunocytochemical techniques (Richards et al., 1987; Houser et al., 1988; Fritschy et al., 1994; Nusser et al., 1998), quantitative measurements of relative densities of synaptic versus extrasynaptic receptors have not been made in CA1. In cerebellar granule cells, extrasynaptic receptors occur at much lower density than synaptic receptors (Nusser et al., 1995). In cultured hippocampal neurons, however, only half of $\mathrm{GABA}_{\mathrm{A}}$ 


\section{A $10 \mathrm{mM}$ BAPTA}
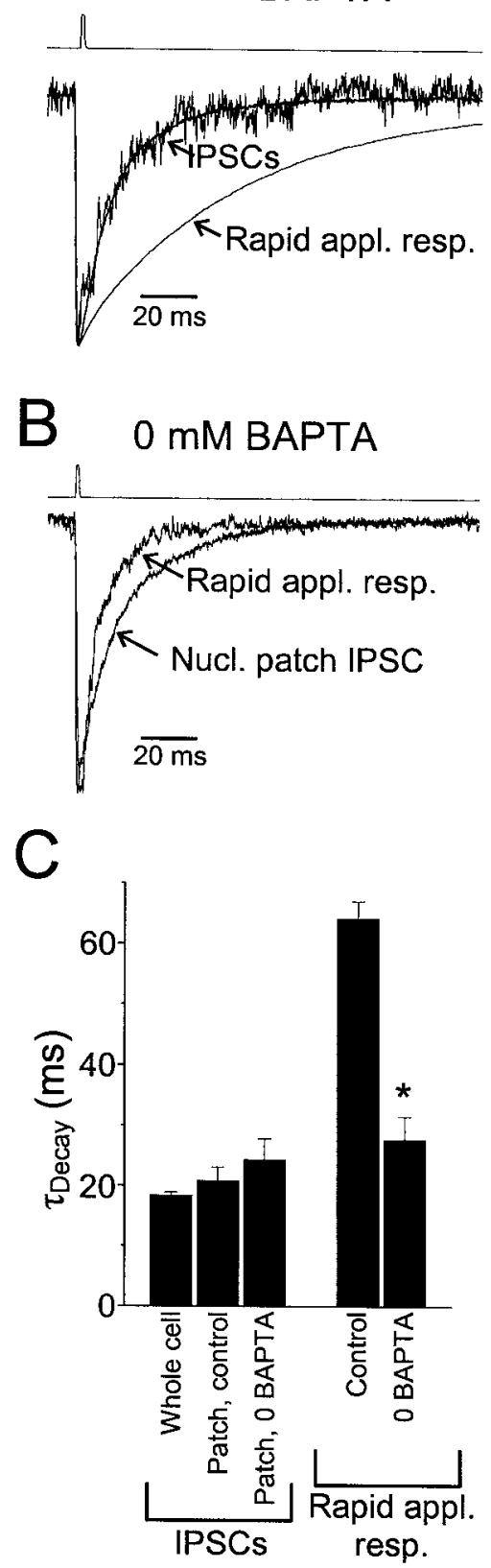

Figure 7. Selective modulation of rapid application responses by elevated calcium. $A$, Normalized whole-cell (smooth trace) and nucleated patch (noisy trace) sIPSCs and rapid application response of the nucleated patch to $1 \mathrm{mM}, 2 \mathrm{msec}$ pulse of GABA recorded with a pipette containing $10 \mathrm{~mm}$ BAPTA. All data were recorded from the same cell. $\tau_{\text {Decay }}$ values were as follows: whole-cell IPSC, $16.8 \mathrm{msec}$; patch IPSC, $15.3 \mathrm{msec}$; rapid application response, $67.8 \mathrm{msec}$. $B$, Normalized nucleated patch IPSC and response in the same patch to a $1 \mathrm{~mm}, 2$ msec GABA pulse recorded in a different patch from $A$ with a pipette containing 0 BAPTA. Note that in 0 BAPTA, the rapid application response is faster than in control, but the IPSC decay is similar. $\tau_{\text {Decay }}$ values were as follows: patch IPSC, 18.6 msec; rapid application response, $7.7 \mathrm{msec}$. $C$, Average weighted time constants of whole-cell and patch sIPSCs under control conditions and with 0 BAPTA, and rapid application responses to $1 \mathrm{~mm}, 2 \mathrm{msec}$ GABA pulses under control conditions and with 0 BAPTA. There was no significant difference between $\tau_{\text {Decay }}$ for the patch IPSC data $(10 \mathrm{~mm}$ BAPTA vs 0 BAPTA: $p>0.4$, Student's $t$ test), but rapid application responses were significantly faster in the absence of BAPTA $\left({ }^{*} p<10^{-6}\right.$, Student's $t$ test). receptor clusters were apposed by presynaptic specializations, the remaining 50\% presumably corresponding to clustered extrasynaptic receptors (Kannenberg et al., 1999). The observation that extrasynaptic receptors may outnumber synaptic receptors in patches is still consistent with enrichment of receptors at synaptic junctions. These areas of high receptor density likely represent $<0.2 \mu \mathrm{m}^{2} /$ synapse (Harris et al., 1985; Halasy and Somogyi, 1993) or $<25 \mu \mathrm{m}^{2}$ for all of the synapses on the cell body, corresponding to $<5 \%$ of the total amount of membrane. Thus, there is at least 5- to 10 -fold enrichment of receptors in the synaptic zone.

\section{Kinetic classes of IPSCs in CA1}

In CA1 pyramidal neurons, two distinct IPSCs are observed (Pearce, 1993; Banks et al., 1998). GABA ${ }_{\mathrm{A} \text {,fast }}$ is the rapidly decaying, somatic IPSC measured in this study, whereas $\mathrm{GABA}_{\mathrm{A} \text {,slow }}$ is mediated by dendritic synapses and has decay kinetics several fold slower than $\mathrm{GABA}_{\mathrm{A} \text {,fast. }}$ Although the basis for this difference in kinetics is unclear, the different pharmacological properties of these two IPSCs suggests that the receptors mediating $\mathrm{GABA}_{\mathrm{A} \text {,fast }}$ and $\mathrm{GABA}_{\mathrm{A} \text {,slow }}$ are distinct (Banks et al., 1998). The observation that two kinetic classes of $\mathrm{GABA}_{\mathrm{A}}$ receptors exist in these cells raises the possibility that $\mathrm{GABA}_{\mathrm{A} \text {,slow }}$ IPSCs are mediated by the same type of receptors that are extrasynaptic at the soma. It may be that proteins responsible for clustering these receptors are targeted only to dendritic regions and that these slow receptors are distributed diffusely in the somatic membrane, but are clustered in the dendritic membrane.

\section{Functional significance of extrasynaptic receptors}

One possible function of extrasynaptic receptors is that they set the resting conductance of the postsynaptic cell by way of tonic activation by ambient GABA or by GABA that spills over from the synaptic clefts of nearby terminals (Brickley et al., 1996; Hausser and Clark, 1997). In cerebellar granule cells, extrasynaptic, $\delta$ subunit-containing receptors have a high affinity for GABA and do not desensitize, making them particularly wellsuited to this task (Saxena and Macdonald, 1994, 1996). The relatively slow deactivation kinetics of extrasynaptic receptors in CA1 may similarly be a specialization appropriate for mediating tonic inhibition.

This role for extrasynaptic receptors would allow endogenous modulators of $\mathrm{GABA}_{\mathrm{A}}$ receptors and GABA uptake to regulate the excitability of the hippocampal network. In addition, some pharmacological agents may act via this mechanism. A number of general anesthetics are able to gate $\mathrm{GABA}_{\mathrm{A}}$ receptors directly (Yang et al., 1992; Belelli et al., 1997; Ueno et al., 1997) and may also increase the sensitivity of these receptors to ambient GABA (Banks and Pearce, 1999). Thus, modulation of extrasynaptic receptors may mediate some of the behavioral effects of general anesthetics. The observation that the volatile anesthetic isoflurane has different effects on synaptic and rapid application responses (Banks et al., 1997) raises the possibility that general anesthetics may differentially target transient versus tonic inhibition, and this could contribute to the complexity of the behavioral effects of these agents.

\section{REFERENCES}

Assaf SY, Chung SH (1984) Release of endogenous $\mathrm{Zn}{ }^{2+}$ from brain tissue during activity. Nature 308:734-736.

Banks MI, Pearce RA (1999) Dual actions of volatile anesthetics on $\mathrm{GABA}_{\mathrm{A}}$ IPSCs: dissociation of blocking and prolonging effects. Anesthesiology 90:120-134. 
Banks MI, Li T-B, Pearce RA (1997) Effects of isoflurane on mIPSCs and excised neuronal GABA $\mathrm{A}_{\mathrm{A}}$ receptors. Soc Neurosci Abstr 23:104.

Banks MI, Li T-B, Pearce RA (1998) The synaptic basis of GABA A,slow. . J Neurosci 18:1305-1317.

Belelli D, Lambert JJ, Peters JA, Wafford K, Whiting PJ (1997) The interaction of the general anesthetic etomidate with the gammaaminobutyric acid type A receptor is influenced by a single amino acid. Proc Natl Acad Sci USA 94:11031-11036.

Berger T, Schwarz C, Kraushaar U, Monyer H (1998) Dentate gyrus basket cell $\mathrm{GABA}_{\mathrm{A}}$ receptors are blocked by $\mathrm{Zn}^{2+}$ via changes of their desensitization kinetics: an in situ patch-clamp and single-cell PCR study. J Neurosci 18:2437-2448.

Brickley SG, Cull-Candy SG, Farrant M (1996) Development of a tonic form of synaptic inhibition in rat cerebellar granule cells resulting from persistent activation of $\mathrm{GABA}_{\mathrm{A}}$ receptors. J Physiol (Lond) 497:753-759.

Brickley SG, Cull-Candy SG, Farrant M (1999) Single-channel properties of synaptic and extrasynaptic $\mathrm{GABA}_{\mathrm{A}}$ receptors suggest differential targeting of receptor subtypes. J Neurosci 19:2960-2973.

Chen QX, Stelzer A, Kay AR, Wong RK (1990) GABA receptor $^{2}$ function is regulated by phosphorylation in acutely dissociated guineapig hippocampal neurones. J Physiol (Lond) 420:207-221.

Clements JD, Lester RA, Tong G, Jahr CE, Westbrook GL (1992) The time course of glutamate in the synaptic cleft. Science 258:1498-1501.

Colquhoun D, Jonas P, Sakmann B (1992) Action of brief pulses of glutamate on AMPA/kainate receptors in patches from different neurones of rat hippocampal slices. J Physiol (Lond) 458:261-287.

Dudel J, Franke C, Hatt H (1992) Rapid activation and desensitization of transmitter-liganded receptor channels by pulses of agonists. Ion Channels 3:207-260.

Edwards FA, Konnerth A, Sakmann B, Takahashi T (1989) A thin slice preparation for patch clamp recordings from neurones of the mammalian central nervous system. Pflügers Arch 414:600-612.

Essrich C, Lorez M, Benson JA, Fritschy JM, Luscher B (1998) Postsynaptic clustering of major $\mathrm{GABA}_{\mathrm{A}}$ receptor subtypes requires the $\gamma_{2}$ subunit and gephyrin. Nat Neurosci 1:563-571.

Frerking M, Wilson M (1996) Saturation of postsynaptic receptors at central synapses? Curr Opin Neurobiol 6:395-403.

Frerking M, Borges S, Wilson M (1995) Variation in GABA mini amplitude is the consequence of variation in transmitter concentration. Neuron 15:885-895

Fritschy JM, Paysan J, Enna A, Mohler H (1994) Switch in the expression of rat $\mathrm{GABA}_{\mathrm{A}}$-receptor subtypes during postnatal development: an immunohistochemical study. J Neurosci 14:5302-5324.

Galarreta M, Hestrin S (1997) Properties of $\mathrm{GABA}_{\mathrm{A}}$ receptors underlying inhibitory synaptic currents in neocortical pyramidal neurons. J Neurosci 17:7220-7227.

Gingrich KJ, Burkat PM (1998) $\mathrm{Zn}^{2+}$ inhibition of recombinant $\mathrm{GABA}_{\mathrm{A}}$ Receptors - an allosteric, state-dependent mechanism determined by the gamma-subunit. J Physiol (Lond) 506:609-625.

Gingrich KJ, Roberts WA, Kass RS (1995) Dependence of the GABA receptor gating kinetics on the alpha-subunit isoform: implications for structure-function relations and synaptic transmission. J Physiol (Lond) 489:529-543.

Halasy K, Somogyi P (1993) Distribution of GABAergic synapses and their targets in the dentate gyrus of rat: a quantitative immunoelectron microscopic analysis. J Hirnforsch 34:299-308.

Hamill OP, Marty A, Neher E, Sakmann B, Sigworth FJ (1981) Improved patch-clamp techniques for high-resolution current recording from cells and cell-free membrane patches. Pflügers Arch 391:85-100.

Harris KM, Marshall PE, Landis DM (1985) Ultrastructural study of cholecystokinin-immunoreactive cells and processes in area CA1 of the rat hippocampus. J Comp Neurol 233:147-158.

Hausser M, Clark BA (1997) Tonic synaptic inhibition modulates neuronal output pattern and spatiotemporal synaptic integration. Neuron 19:665-678.

Hestrin S (1992) Activation and desensitization of glutamate-activated channels mediating fast excitatory synaptic currents in the visual cortex. Neuron 9:991-999.

Hill MW, Reddy PA, Covey DF, Rothman SM (1998) Contribution of subsaturating GABA concentrations to IPSCs in cultured hippocampal neurons. J Neurosci 18:5103-5111.

Houser CR, Olsen RW, Richards JG, Mohler H (1988) Immunohistochemical localization of benzodiazepine/GABA $\mathrm{G}_{\mathrm{A}}$ receptors in the human hippocampal formation. J Neurosci 8:1370-1383.
Inoue M, Oomura Y, Yakushiji T, Akaike N (1986) Intracellular calcium ions decrease the affinity of the GABA receptor. Nature 324:156-158.

Isaacson JS, Solis JM, Nicoll RA (1993) Local and diffuse synaptic actions of GABA in the hippocampus. Neuron 10:165-175.

Jack JJ, Noble D, Tsien RW (1983) Electric current flow in excitable cells. Oxford: Oxford UP.

Jackson MB (1992) Cable analysis with the whole-cell patch clamp. Theory and experiment. Biophys J 61:756-766.

Jones MV, Westbrook GL (1995) Desensitized states prolong $\mathrm{GABA}_{\mathrm{A}}$ channel responses to brief agonist pulses. Neuron 15:181-191.

Jones MV, Westbrook GL (1996) The impact of receptor desensitization on fast synaptic transmission. Trends Neurosci 19:96-101.

Jones MV, Westbrook GL (1997) Shaping of IPSCs by endogenous calcineurin activity. J Neurosci 17:7626-7633.

Jones MV, Sahara Y, Dzubay JA, Westbrook GL (1998) Defining affinity with the $\mathrm{GABA}_{\mathrm{A}}$ receptor. J Neurosci 18:8590-8604.

Kannenberg K, Sieghart W, Reuter H (1999) Clusters of GABA receptors on cultured hippocampal cells correlate only partially with functional synapses. Eur J Neurosci 11:1256-1264.

Krishek BJ, Amato A, Connolly CN, Moss SJ, Smart TG (1996) Proton sensitivity of the $\mathrm{GABA}_{\mathrm{A}}$ receptor is associated with the receptor subunit composition. J Physiol (Lond) 492:431-443.

Legendre P (1998) A reluctant gating mode of glycine receptor channels determines the time course of inhibitory miniature synaptic events in zebrafish hindbrain neurons. J Neurosci 18:2856-2870.

Lerma J, Herranz AS, Herreras O, Abraira V, Martin DR (1986) In vivo determination of extracellular concentration of amino acids in the rat hippocampus. A method based on brain dialysis and computerized analysis. Brain Res 384:145-155.

Lester RA, Clements JD, Westbrook GL, Jahr CE (1990) Channel kinetics determine the time course of NMDA receptor-mediated synaptic currents. Nature 346:565-567.

Macdonald RL, Rogers CJ, Twyman RE (1989) Kinetic properties of the $\mathrm{GABA}_{\mathrm{A}}$ receptor main conductance state of mouse spinal cord neurones in culture. J Physiol (Lond) 410:479-499.

Maconochie DJ, Zempel JM, Steinbach JH (1994) How quickly can $\mathrm{GABA}_{\mathrm{A}}$ receptors open? Neuron 12:61-71.

Martina M, Kilic G, Cherubini E (1994) The effect of intracellular $\mathrm{Ca}^{2+}$ on GABA-activated currents in cerebellar granule cells in culture. J Membr Biol 142:209-216.

McClellan AL, Twyman RE (1999) Receptor system response kinetics reveal functional subtypes of native murine and recombinant human $\mathrm{GABA}_{\mathrm{A}}$ receptors. J Physiol (Lond) 515:711-727.

Mellor JR, Randall AD (1997) Frequency-dependent actions of benzodiazepines on $\mathrm{GABA}_{\mathrm{A}}$ receptors in cultured murine cerebellar granule cells. J Physiol (Lond) 503:353-369.

Miesenbock G, Deangelis DA, Rothman JE (1998) Visualizing secretion and synaptic transmission with $\mathrm{pH}$-sensitive green fluorescent proteins. Nature 394:192-195.

Mozrzymas JW, Cherubini E (1998) Changes in intracellular calcium concentration affect desensitization of $\mathrm{GABA}_{\mathrm{A}}$ receptors in acutely dissociated P2-P6 rat hippocampal neurons. J Neurophysiol 79:1321-1328.

Mozrzymas JW, Barberis A, Michalak K, Cherubini E (1999) Chlorpromazine inhibits miniature GABAergic currents by reducing the binding and by increasing the unbinding rate of $\mathrm{GABA}_{\mathrm{A}}$ receptors. J Neurosci 19:2474-2488.

Nusser Z, Roberts JD, Baude A, Richards JG, Somogyi P (1995) Relative densities of synaptic and extrasynaptic $\mathrm{GABA}_{\mathrm{A}}$ receptors on cerebellar granule cells as determined by a quantitative immunogold method. J Neurosci 15:2948-2960.

Nusser Z, Cull-Candy SG, Farrant M (1997) Differences in synaptic $\mathrm{GABA}_{\mathrm{A}}$ receptor number underlie variation in GABA mini amplitude. Neuron 19:697-709.

Nusser Z, Sieghart W, Somogyi P (1998) Segregation of different $\mathrm{GABA}_{\mathrm{A}}$ receptors to synaptic and extrasynaptic membranes of cerebellar granule cells. J Neurosci 18:1693-1703.

Pearce RA (1993) Physiological evidence for two distinct $\mathrm{GABA}_{\mathrm{A}}$ responses in rat hippocampus. Neuron 10:189-200.

Perrais D, Ropert N (1999) Effect of zolpidem on miniature IPSCs and occupancy of postsynaptic $\mathrm{GABA}_{\mathrm{A}}$ receptors in central synapses. J Neurosci 19:578-588.

Poisbeau P, Cheney MC, Browning MD, Mody I (1999) Modulation of synaptic $\mathrm{GABA}_{\mathrm{A}}$ receptor function by PKA and PKC in adult hippocampal neurons. J Neurosci 19:674-683. 
Richards JG, Schoch P, Haring P, Takacs B, Mohler H (1987) Resolving $\mathrm{GABA}_{A}$ /benzodiazepine receptors: cellular and subcellular localization in the CNS with monoclonal antibodies. J Neurosci 7:1866-1886.

Rosenmund C, Westbrook GL (1993) Calcium-induced actin depolymerization reduces NMDA channel activity. Neuron 10:805-814.

Sather W, Dieudonne S, MacDonald JF, Ascher P (1992) Activation and desensitization of $N$-methyl-D-aspartate receptors in nucleated outsideout patches from mouse neurones. J Physiol (Lond) 450:643-672.

Saxena NC, Macdonald RL (1994) Assembly of GABA A $_{\text {receptor sub- }}$ units: role of the delta subunit. J Neurosci 14:7077-7086.

Saxena NC, Macdonald RL (1996) Properties of putative cerebellar gamma-aminobutyric $\operatorname{acid}_{\mathrm{A}}$ receptor isoforms. Mol Pharmacol 49:567-579.

Stelzer A, Shi H (1994) Impairment of $\mathrm{GABA}_{\mathrm{A}}$ receptor function by $\mathrm{N}$-methyl-D-aspartate-mediated calcium influx in isolated CA1 pyramidal cells. Neuroscience 62:813-828.

Tanelian DL, Kosek P, Mody I, MacIver MB (1993) The role of the $\mathrm{GABA}_{\mathrm{A}}$ receptor/chloride channel complex in anesthesia. Anesthesiology 78:757-776.

Tia S, Wang JF, Kotchabhakdi N, Vicini S (1996a) Developmental changes of inhibitory synaptic currents in cerebellar granule neuronsrole of $\mathrm{GABA}_{\mathrm{A}}$ receptor $\alpha_{6}$ subunit. J Neurosci 16:3630-3640.

Tia S, Wang JF, Kotchabhakdi N, Vicini S (1996b) Distinct deactivation and desensitization kinetics of recombinant $\mathrm{GABA}_{\mathrm{A}}$ receptors. Neuropharmacology 35:1375-1382.
Tossman U, Jonsson G, Ungerstedt U (1986) Regional distribution and extracellular levels of amino acids in rat central nervous system. Acta Physiol Scand 127:533-545.

Trussell LO, Fischbach GD (1989) Glutamate receptor desensitization and its role in synaptic transmission. Neuron 3:209-218.

Ueno S, Bracamontes J, Zorumski C, Weiss DS, Steinbach JH (1997) Bicuculline and gabazine are allosteric inhibitors of channel opening of the GABAA receptor. J Neurosci 17:625-634.

Verdoorn TA (1994) Formation of heteromeric gamma-aminobutyric acid type A receptors containing two different alpha subunits. Mol Pharmacol 45:475-480.

Vicini S, Alho H, Costa E, Mienville JM, Santi MR, Vaccarino FM (1986) Modulation of gamma-aminobutyric acid-mediated inhibitory synaptic currents in dissociated cortical cell cultures. Proc Natl Acad Sci USA 83:9269-9273.

Westbrook GL, Mayer ML (1987) Micromolar concentrations of $\mathrm{Zn}^{2+}$ antagonize NMDA and GABA responses of hippocampal neurons. Nature 328:640-643.

Yang J, Isenberg KE, Zorumski CF (1992) Volatile anesthetics gate a chloride current in postnatal rat hippocampal neurons. FASEB J 6:914-918.

Zhu WJ, Vicini S (1997) Neurosteroid prolongs GABA A $_{\text {chanel deac- }}$ tivation by altering kinetics of desensitized states. J Neurosci 17:40224031. 